\title{
Late-onset TNF receptor-associated periodic syndrome presenting as recurrent urticarial rash and lymph nodes
}

\author{
Halil Yildiz, ${ }^{1}$ Stoian loana Andreea, ${ }^{2}$ Diane Declaye, ${ }^{3}$ Jean Cyr Yombi ${ }^{4}$
}

${ }^{1}$ Medecine Interne, Cliniques Universitaires Saint-Luc, Brussels, Belgium ${ }^{2}$ Nuclear Medicine, Cliniques Universitaires Saint-Luc, Brussels, Belgium

${ }^{3}$ Department of Dermatology, Cliniques Universitaires SaintLuc, Brussels, Belgium

${ }^{4}$ Medecine Interne, Cliniques Universitaires Saint-Luc, Brussels, Belgium

\section{Correspondence to}

Dr Halil Yildiz,

halil.yildiz@uclouvain.be

Accepted 9 June 2018

\section{DESCRIPTION}

A 35-year-old Caucasian woman was referred by a general practitioner to our medical ward because she was suffering from recurrent arthralgia, urticarial rash with mild pruritus and cervical lymph nodes. There was no sign of arthritis, any fever, chills or night sweats, but she had lost $2.5 \mathrm{~kg}$ in 3 months. The average lengths of symptoms were more than 6 weeks.

She presented the same symptoms with cervical lymph nodes when she was 24 years old. She received doxycycline for a suspicion of Lyme disease and the evolution was favourable after 2 weeks of treatment. However, serology was not compatible with recent Lyme disease. Since then, the frequencies of the attacks were rare but occurred once a year.
The routine blood tests were normal except a slightly elevated $\mathrm{C}$ reactive protein at $12 \mathrm{mg} / \mathrm{L}$ (normal value $<5 \mathrm{mg} / \mathrm{L}$ ). Infectious serologies for Cytomegalovirus, Epstein-Barr virus, HIV, hepatitis $\mathrm{C}$ and B, Brucella, Bartonella henselae and syphilis were negative as were autoimmune serologies (antinuclear antibodies, antineutrophil cytoplasmic antibodies). Serum IgD level was normal. Urinalysis was normal. A PET/CT showed multiple hypermetabolic lymph nodes above and below the diaphragm (figure 1).

A lymph node cervical biopsy showed a benign follicular hyperplasia without evidence of lymphoma, granuloma or neoplasia. Aerobic, anaerobic and mycobacterial culture were also negative. A skin biopsy confirmed urticarial lesions without sign of vasculitis or mastocytosis.
D Check for updates

(C) BMJ Publishing Group Limited 2018. No commercial re-use. See rights and permissions. Published by BMJ.

To cite: Yildiz $\mathrm{H}_{1}$ Andreea $\mathrm{SI}$, Declaye D, et al. BMJ Case Rep Published Online First: [please include Day Month Year]. doi:10.1136/bcr-2018 225938

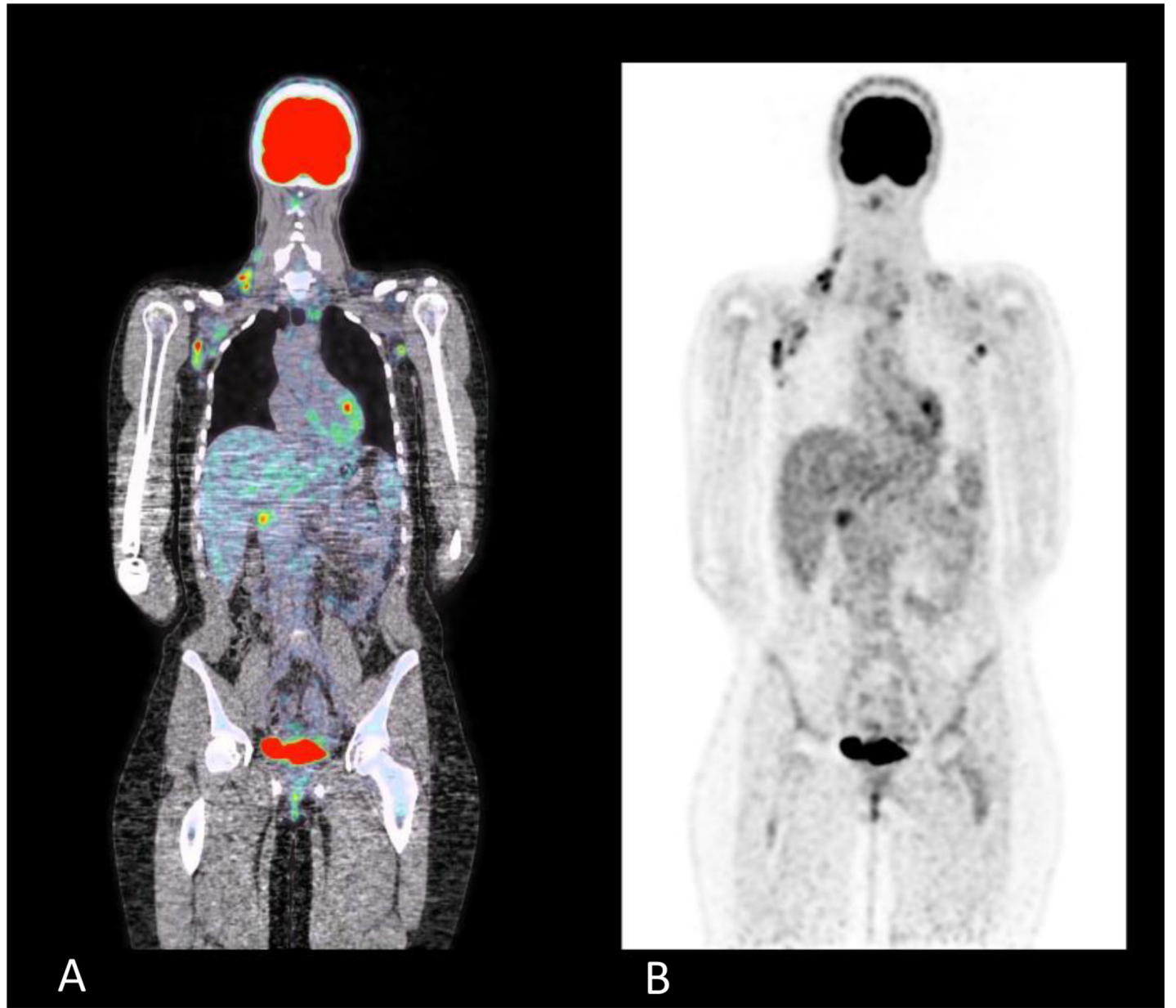

Figure $1 \mathrm{~A}$ and $\mathrm{B},{ }^{18} \mathrm{~F}-\mathrm{FDG}$ PET/CT showing multiple FDG-avid lymph nodes on both sides of the diaphragm. 
Even though the clinical characteristics were unusual (late onset, no fever, urticarial rash and lymphadenopathies during more than 6 weeks), an autoinflammatory disease was suspected. With her oral consent, we performed a screening for genetic autoinflammatory diseases. Four months later, we found a mutation of TNFRSF1A gene (heterozygous variant c.362G>A), which led us to the diagnosis of an atypical form of tumour necrosis factor receptor-1-associated periodic syndrome (TRAPS). We decided to not treat the patient since the symptoms improved spontaneously (after 2 months) and the frequency of the attacks was rare (once a year). Globally, it takes 11 years between the first attacks and the diagnosis. Our patient's father and mother were originally from Italy and France, respectively. There was no familial history of periodic syndrome. A genetic counselling was indicated but not performed since our patient did not want further analysis.

Clinicians should know that every periodic syndrome has a wide range of clinical presentation and that classical descriptions are based on characteristics found in cohort studies, sometimes even small series. ${ }^{1}$ In our patient, late-onset recurrent urticarial

\section{Learning points}

- Urticaria ends with very different diagnosis including autoinflammatory diseases.

- Tumour necrosis factor receptor-1-associated periodic syndrome (TRAPS) should be suspected even without fever.

- TRAPS is a rare disease with low prevalence. rash was the most important symptom. It can be easily mistaken for chronic urticaria and leads to unnecessary treatment. However, when taking care of urticaria, there are symptoms that should alarm the clinicians (to not miss autoinflammatory diseases) such as fever, myalgia, arthralgia, abdominal pain, eye redness, meningeal inflammation, lymph nodes and inflammatory syndrome on blood test. ${ }^{2}$ TRAPS is a rare and dominantly inherited disease, but de novo mutation is possible. The disease has a low prevalence estimated at one per million individuals and is characterised by recurrent febrile attacks and blood inflammation. However, atypical presentations are described and need to be recognised. ${ }^{3}$ In our case, for example, multiple lymphadenopathies were present and persisted for more than 6 weeks, which is not classical for TRAPS.

Contributors $\mathrm{HY}$ and JCY helped in the management of the patient and writing of the paper. SIA helped in the interpretation of the PET/CT. DD worked on dermatology and helped in the management of the patient.

Funding The authors have not declared a specific grant for this research from any funding agency in the public, commercial or not-for-profit sectors.

Competing interests None declared.

Patient consent Obtained.

Provenance and peer review Not commissioned; externally peer reviewed.

\section{REFERENCES}

1 Hoffman HM, Broderick L. Editorial: It just takes one: somatic mosaicism in autoinflammatory disease. Arthritis Rheumatol 2017;69:253-6.

2 Krause K, Grattan CE, Bindslev-Jensen C, et al. How not to miss autoinflammatory diseases masquerading as urticaria. Allergy 2012;64:n/a-7.

3 Rezaei N. TNF-receptor-associated periodic syndrome (TRAPS): an autosomal dominant multisystem disorder. Clin Rheumatol 2006;25:773-7.

Copyright 2018 BMJ Publishing Group. All rights reserved. For permission to reuse any of this content visit

http://group.bmj.com/group/rights-licensing/permissions.

BMJ Case Report Fellows may re-use this article for personal use and teaching without any further permission.

Become a Fellow of BMJ Case Reports today and you can:

- Submit as many cases as you like

- Enjoy fast sympathetic peer review and rapid publication of accepted articles

- Access all the published articles

Re-use any of the published material for personal use and teaching without further permission

For information on Institutional Fellowships contact consortiasales@bmjgroup.com

Visit casereports.bmj.com for more articles like this and to become a Fellow 